Dhaka Univ. J. Biol. Sci. 30(1): 69-78, 2021 (January)

\title{
PLANKTON COMPOSITION OF HAKALUKI HAOR OF MOULVIBAZAR, BANGLADESH
}

\author{
Mohammad Azmal Hossain Bhuiyan* ${ }^{*}$ Mahin Mohid, SAM Shariar Islam ${ }^{1}$, \\ Abu Kowser, Md Rasikul Islam, Shahina Akter Kakoly, Saiful Islam and \\ MONIRUZZAMAN KHONDKER \\ Department of Botany, University of Dhaka, Dhaka-1000, Bangladesh
}

Keywords: Phytoplankton, Zooplankton, Hakaluki Haor, Physicochemical variables, Chlorophyll-a

\begin{abstract}
In the present study, physicochemical and biological variables related to the water quality of Hakaluki Haor were studied. Three study stations viz. Bakshimul, Jalabeel and Dudhai were investigated because of an event of mass scale of dead fish and other aquatic organisms were reported. The stations had water depths from 2.74 $5.13 \mathrm{~m}$ and Secchi Disc Transparency were $0.74-1.91 \mathrm{~m}$. The air and water temperature among the three stations ranged from $28.2-30.4^{\circ} \mathrm{C}$ and $21.8-28.8^{\circ} \mathrm{C}$, respectively. TDS ranged from $35-42 \mathrm{mg} \Lambda$, while the electric conductivity of water showed 40 - $50 \mu \mathrm{S} / \mathrm{cm}$. SRP, nitrate and SRS ranged from 10.68 - $12.32 \mu \mathrm{g} / \mathrm{l}, 0.116$ $0.122 \mathrm{mg} \Lambda$ and, $16.08-35.42 \mathrm{mg} \Lambda$, respectively. The concentration of DO was very poor which ranged from $2.8-5.4 \mathrm{mg} /$. In all the three studied stations, the free $\mathrm{CO}_{2}$ concentration was $0.096 \mathrm{mg} /$. Chlorophyll-a value was moderate in all the three stations (ranged within 34.67 and $40.60 \mu \mathrm{g} /$ ). The phaeopigment concentration was low and ranged from 1.51- $8.72 \mu \mathrm{g} / \mathrm{l}$ among the studied stations. Concentration of ammonia was much higher (1.03 - $1.72 \mathrm{mg} \Lambda$ ) than the standard value for Bangladesh (0.5 $\mathrm{mg}$ /). From this analysis, it is observed that during fish kill event the concentration of ammonia was higher with low DO content which might have resulted because of the decomposition of upper foliar parts of the rice plant due to the sudden inundation. Gross $\alpha$ and $\beta$ counts were found to be 0.01 and $0.10 \mathrm{~Bq} A$ in the Haor water at the time of fish kill. From the planktonic community, 16 phytoplanktons from green algae, 14 euglenoids, 5 diatoms, 5 dinoflagellates and 12 zooplankton species were recorded. A shift in the $\mathrm{pH}$ of the Haor water from acidic to alkaline might have occurred during the last 3 decades. A detailed limnological study covering the climatic seasons of Bangladesh has been recommended to be carried out for Hakaluki Haor.
\end{abstract}

\section{Introduction}

Haors are large sized specialized wetland ecosystems abundantly present in the districts situated in the north-eastern arm of Bangladesh's map (1). They contain many

*Author for correspondence: \bhuiyan.azmal@du.ac.bd>. 1Plant Biotechnology and Genetic Engineering Division Institute of Food and Radiation Biology (IFRB), AERE, Bangladesh Atomic Energy Commission, Savar, Dhaka - 1349, Bangladesh.

DOI: https://doi.org/10.3329/dujbs.v30i1.51810 
shallow tectonic depressions and during monsoon, they are filled up with water taking a very large shape. The highest numbers of haors are present in the Sunamganj District, where the total area covered by this ecosystem is $73.17 \%$ of the District's total area. In this Haor Basin of Bangladesh, Tanguar Haor has been declared as an Ecologically Critical Area (ECA) by the Government of the People's Republic of Bangladesh and as a Ramsar Site by UNESCO in 1999. The physicochemical condition of this Haor from Rauar and Watch Tower Station were studied ${ }^{(2-5)}$. Phytoplankton composition of at least 5 out of 10 algal divisions of this Haor were also worked out (2-5). Considering area, the largest haor ecosystem of Bangladesh named Hakaluki is situated in the districts of Moulvibazar and Sylhet. Its total area is $181.15 \mathrm{~km}^{2}$ and supporting 558 species of birds and other aquatic animals. Hakaluki Haor also supports a number of wetland trees and other aquatic plants. The first hydrobiological research on Hakaluki Haor was carried out where a list of phytoplankton, benthic algae and macrophytes growing in the pelagic and littoral area of the Haor were published(6). Physicochemical attributes of Hakaluki Haor also studied $^{(7)}$. In 2017, an untimely flash flood occurred in April causing inundation of vast areas of its rice fields and an instant mortality of fishes, aquatic birds, ducks, reptiles, etc. were also reported. The present investigation was carried out on the planktonic flora and fauna and on some water quality parameters of the Haor water at three different places of occurrence of mass scale fish mortality in 2017.

\section{Materials and Methods}

For the collection of plankton and water samples, the Hakaluki Haor was visited on April 28, 2017. Collections were made at three different stations of the Haor viz. Bakshimul, Jalabeel and Dudhai where fish kills were reported. By interviewing local residents and a well acquainted boatman, the places of investigation was reached using an engine-boat. Water depth $(Z)$ of the station was measured with the help of a graduated rope carrying a weight at the end and Secchi depth (Zs) was measured by a Secchi Disc( ${ }^{(8)}$. A field multimeter (Hanna Multi Instruments Code - HI9813-6, SND0108196, Romania) was used to measure $\mathrm{pH}$, electrical conductivity (Cond.) and total dissolved solids (TDS) in situ. Clear glass stoppered Pyrex BOD bottles (125 ml cap.) in duplicate were filled with the Haor water and was immediately fixed by adding $1 \mathrm{ml}$ of each of manganous sulphate and Winkler's reagent to the sample. The bottles were stoppered, sealed and carried to the laboratory keeping those submerged under water in a plastic bucket for the analysis of dissolved oxygen (DO). A Schindler-Patalas (modified) depth sampler (5 L cap.) was used to collect $0.5 \mathrm{~m}$ integrated water sample from the

pelagic of each selected station. While collecting the water sample, the water temperature was read with the help of a mercury thermometer housed in the sampler. Air temperature was recorded with another piece of identical centigrade thermometer. Water sample, collected from the pelagic was poured into a black light proof canister (5 L cap.) 
up to the brim; screw-capped, sealed and was transported to the laboratory for chemical analysis. One Pyrex clear glass bottle (1 L cap.) containing $1 \mathrm{ml}$ of Lugol's iodine (fixative) was just filled carefully by decanting water through the stopcock of the Schindler's sampler and the bottle was sealed and transported to the laboratory for sedimentation of plankton. Another plankton sample was also collected by passing $100 \mathrm{~L}$ of pelagic water through a plankton net $(37 \mu \mathrm{m})$ and the concentrate was preserved with $4 \%$ buffered formaldehyde in a sample vial. Both the sedimented and plankton net concentrates were used for qualitative study of plankton. Procedures for collecting samples from all the studied stations were same. After collection, the samples were given ice packs wherever necessary and transported to the National Professor A. K. M. Nurul Islam Laboratory, Department of Botany, University of Dhaka for further analyses. Time period required to transport the sample to the Dhaka University Laboratory was nearly $12 \mathrm{~h}$ after the last collection of samples in the Haor was completed. After reaching the laboratory, measurements of the water quality parameters were completed within the next 48 hours except the qualitative and quantitative aspects of plankton. The analytical work began immediately with the filtration of sample water. A Sartorius Filtration Device (Göttingen, Germany) fitted with Whatman GF/F (48 mm circles) filter paper was used to filter the sample. The residue collected on the filter paper was used to determine the concentration of chlorophyll-a (Chl-a) and phaeopigment (Phaeo.) while the filtrate was used for the analysis of different water quality parameters. The chl-a and phaeo., soluble reactive phosphorus (SRP), soluble reactive silicate (SRS) and nitrate nitrogen $\left(\mathrm{NO}_{3}-\mathrm{N}\right)$ were determined by using the methods of Marker et al. ${ }^{(9)}$, Murphy and Riley(10), Wetzel and Likens ${ }^{(11)}$ and Müller and Wiedemann ${ }^{(12)}$, respectively.

Microscopic observation for the qualitative analysis of phyto- and zooplankton were done with the help of a Zeiss Axio Lab. A1 Research Microscope attached with a Zeiss AxiocamERc 5s, Germany; a photographic attachment. Imaging of plankton species together with the data collection on cell length and breadth were recorded with the help of the same microscope. The taxa were identified with the help of Ahmed et al.(13,14), Khondker et al.(15), Hustedt(16), Ling and Tylor ${ }^{(17)}$, Prescott(18) and Edmondson ${ }^{(19)}$.

\section{Results and Discussion}

Table 1 shows, the data on physicochemical and biological variables recorded from three different stations of the Hakaluki Haor. By interviewing local residents living in the catchment of the affected Haor, it was known that at Bakshimul (1) station, the mortality of fishes were high. The other two stations namely, Jalabeel and Dudhai received moderate to a little fish kill. Relatively high concentration of TDS, conductivity, ammonium $\left(\mathrm{NH}_{4}+\right)$ and silicate (SRS) were recorded from the Bakshimul Station of the Hakaluki Haor (Table 1). The DO concentration in the same station was found low (Table 1). 


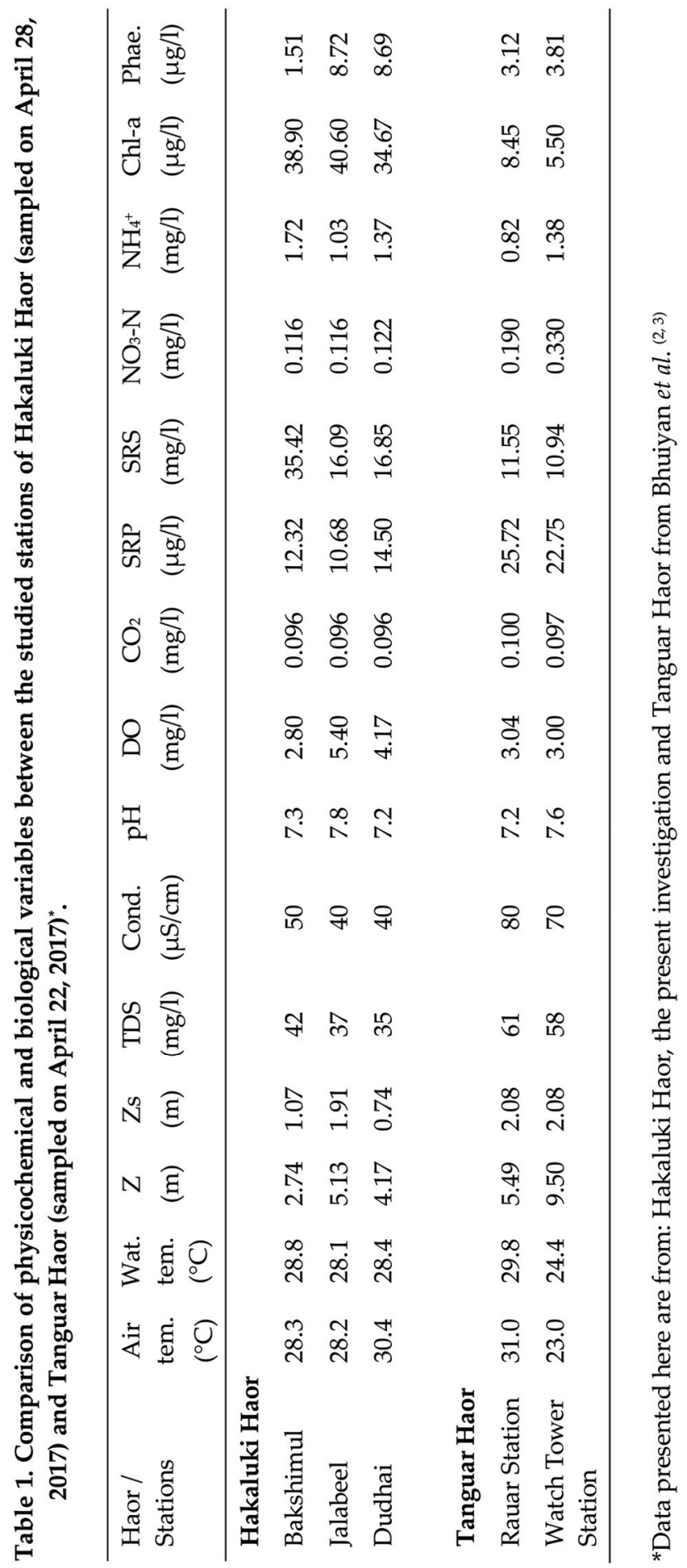


By analyzing the data, it could be said that a low DO accompanied with a relatively high ammonia concentration in water might be associated with the fish kill. The condition could have resulted because of the decomposition of the foliar part of the inundated rice plants in the Haor. The radioactivity levels of the sample water were analyzed and the gross $\alpha$ and $\beta$ were found to be 0.01 and $0.10 \mathrm{~Bq} /$.

For Hakaluki Haor, mean water temperature $26.8^{\circ} \mathrm{C}$, Secchi depth $0.43 \mathrm{~m}$, TDS 68.68 $\mathrm{mg} \Lambda$, conductivity $141.42 \mu \mathrm{S} / \mathrm{cm}, \mathrm{pH} 6.44$ and DO $4.90 \mathrm{mg} \Lambda$ were reported(7). This indicates low $\mathrm{pH}$ turbid water having a relatively high TDS and electrical conductivity of Hakaluki Haor.

During the fish kill disaster period of 2017, two stations of Tanguar Haor were sampled (on April 22, 2017) and the physicochemical and biological variables are compared in Table 1.
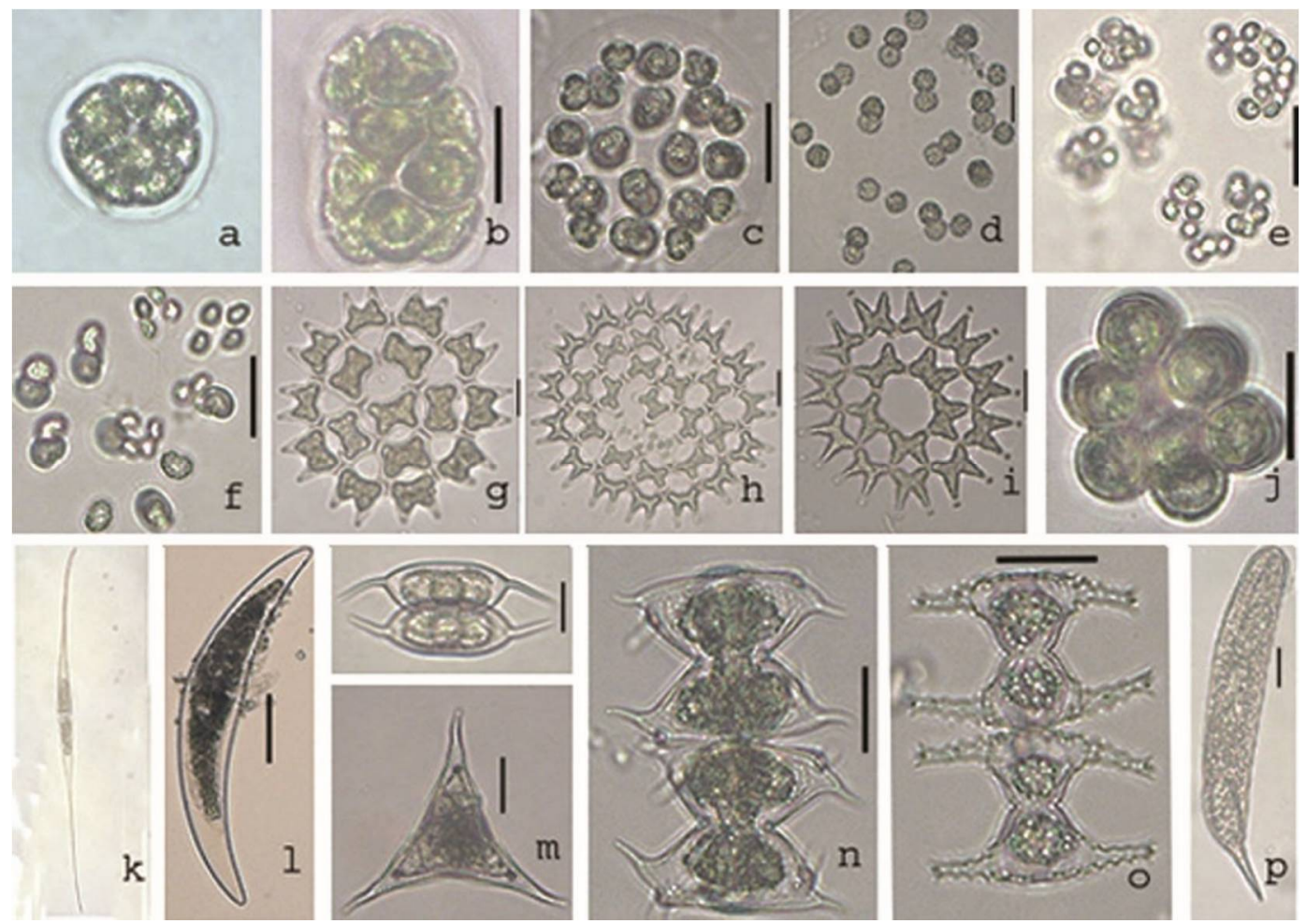

Figs 1a-p. Showing the species belonging to the algal class Chlorophyceae from Hakaluki Haor. a. Pandorina sp., b. P. morum, c. Eudorina elegans, d. Pleudorina sp., e. Dictyosphaerium pulchellum, f. Dimorphococcus sp., g. Padiastrum boryanum, h. P. clathratum, i. P. duplex, j. Coelastrum microporum, k. Closterium kuetzingianum var. kuetzingianum, . 1, Cl. moniliforme, m. Tetraedron trigonum, n. Arthrodesmus curvatum, o. Staurodesmus gibberulus, p. Euglena oxyuris var. charkowiensis. 

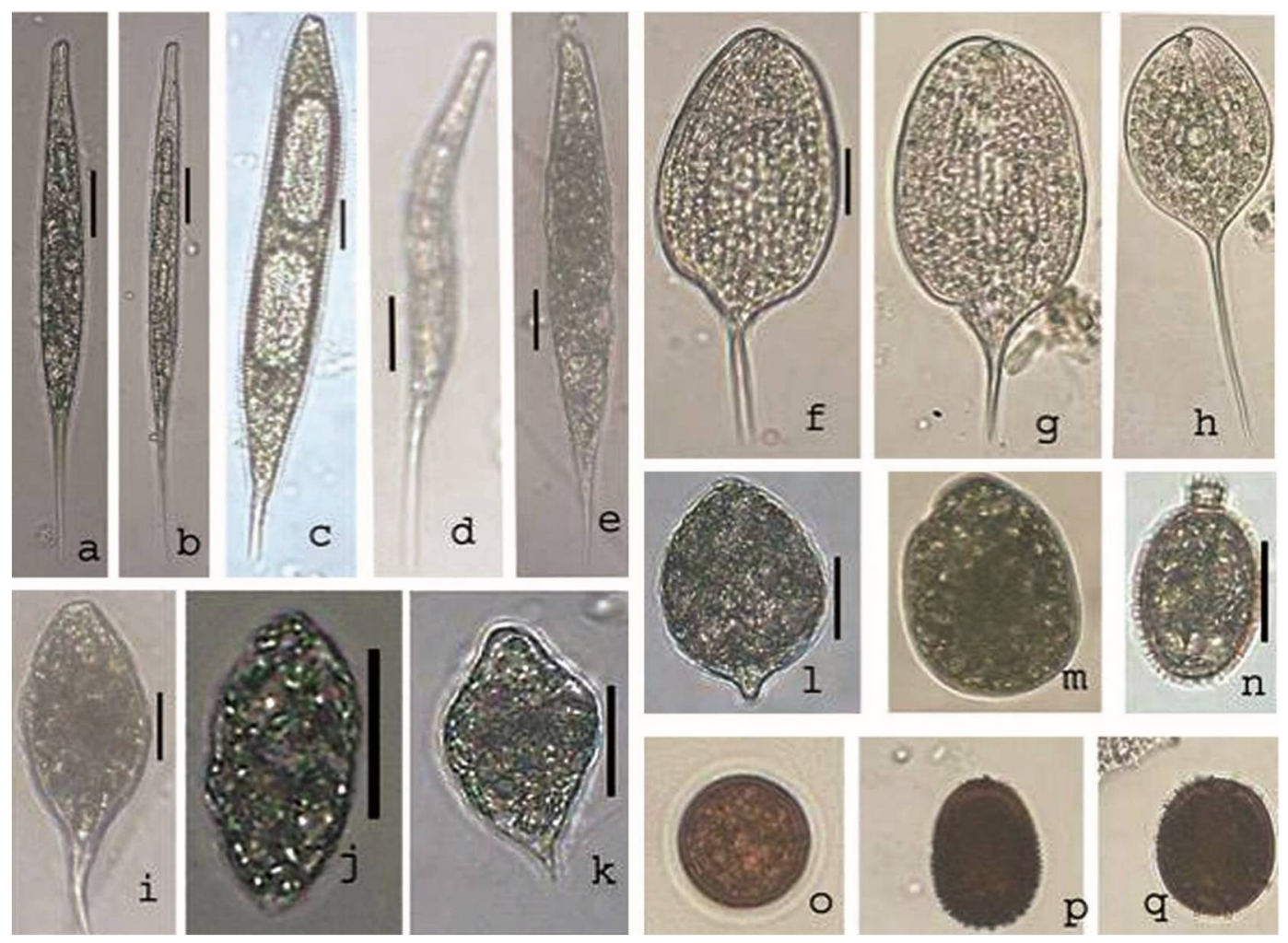

Figs 2a-q. Members of the algal class Euglenophyceae from the Hakaluki Haor. a. Euglena acus var. rigida, b. E. acus var. longicauda, c. E. spirogyra, d. E. acus, e. Euglena sp., f-g. Phacus longicauda var. rotunda, h. P. longicauda var. major, i. P. ranula, j-k. Euglena sanguinea, l. Lepocinclis ovum var. major, m. L. salina, n. Trachelomonas mirabilis var. minor, o. T. volvocina, p-q. T. hispida.

Data presented in Table 1, reveals that the air and water temperature and $\mathrm{pH}$ and $\mathrm{CO}_{2}$ concentration for both the Haor ecosystems were almost same. However, water depth at Watch Tower Station of Tanguar Haor $(9.50 \mathrm{~m})$ and water transparency and SRP concentration were higher than in Hakaluki Haor (Table 1). The Jalabeel Station of Hakaluki Haor represented the highest water depth $(5.71 \mathrm{~m})$. Though SRP of Hakaluki Haor is lower (10.68-14.50 $\mu \mathrm{g} /$ ) but it supports a good phytoplankton biomass as chl-a (34.67 - $40.60 \mu \mathrm{g} /$ ). The situation is just reverse in Tanguar Haor i.e., relatively high phosphorus (22.75 - $25.72 \mu \mathrm{g} \Lambda)$ but low chl-a (5.50 - $8.45 \mu \mathrm{g} \Lambda)$. Tanguar Haor is situated in the extreme north-eastern part of Bangladesh adjacent to the foothill region of the Meghalaya Plateau, India. This ecosystem has been receiving water as surface washout and seepage from the hilly regions where Cherrapunji, India is situated. On the other hand, Hakaluki is situated in the south-eastern fringe of Bangladesh i.e., in the Central Sylhet lowland. The hydrological regime of this Haor is based on the surface washout 
from the agricultural fields and the drainage basins of the river Kushiyara. The regional geomorphology of both the Haors might have affected the water quality.

In the present investigation, 16 greens, 14 euglenoids and 10 Chrysophytes taxa from phytoplankton and 12 taxa of zooplankton were recorded (Figs 1a-p, Figs 2a-q, Figs 3a-1 and Figs 4a-p). Islam and Paul ${ }^{(6)}$ reported 30 taxa from green algae and 6 taxa from each of euglenoids and chrysophytes. There is no previous report on the zooplankton community of the Hakaluk Haor. In the present investigation, 12 taxa of zooplankton have reported for the first time from the Hakaluki Haor (Figs. 4a-p). By comparing the data of Islam and Paul(6), it could be said that the Haor water is still dominated by green algae but the number of euglenoids and chrysophytes might have increased recently. A major shift in the $\mathrm{pH}$ value $(7.2$ - 7.8) towards alkaline range has been reported in the present investigation compared to that reported value $(\mathrm{pH}, 5.0$ - 5.5) by Islam and Paul(6).
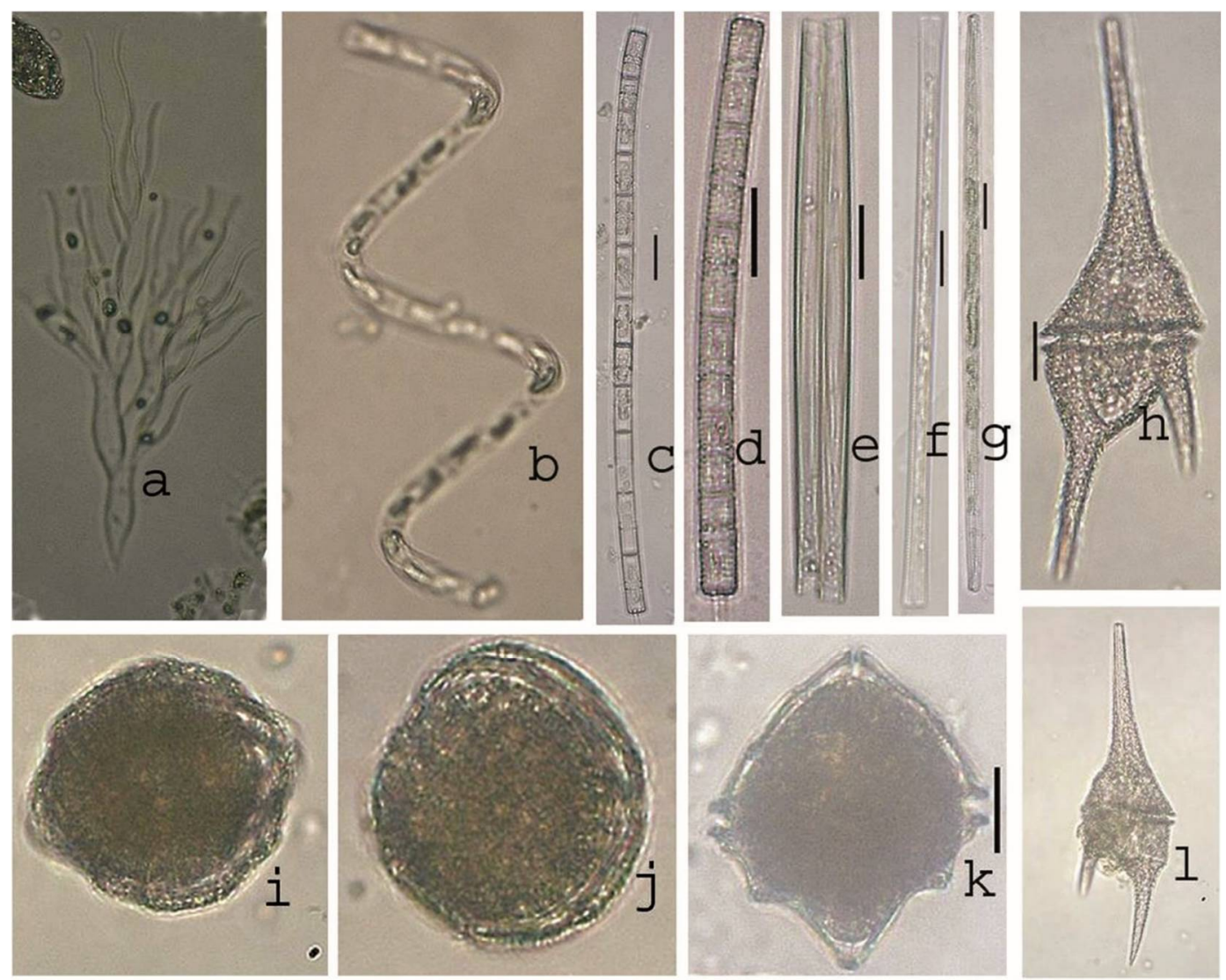

Figs 3a-l: Chrysophytes of Hakaluki Haor. a. Dinobryon cylindricum, b. Melosira granulata var. angustissima f. spiralis, c. M. granulata var. angustissima, d. M. italica, e. Fragilaria virescens, f-g. Synedra ulna, h. Ceratium hirundinella, i-j. Peridinium cinctum, k. Peridinium sp., l. Ceratium sp. 

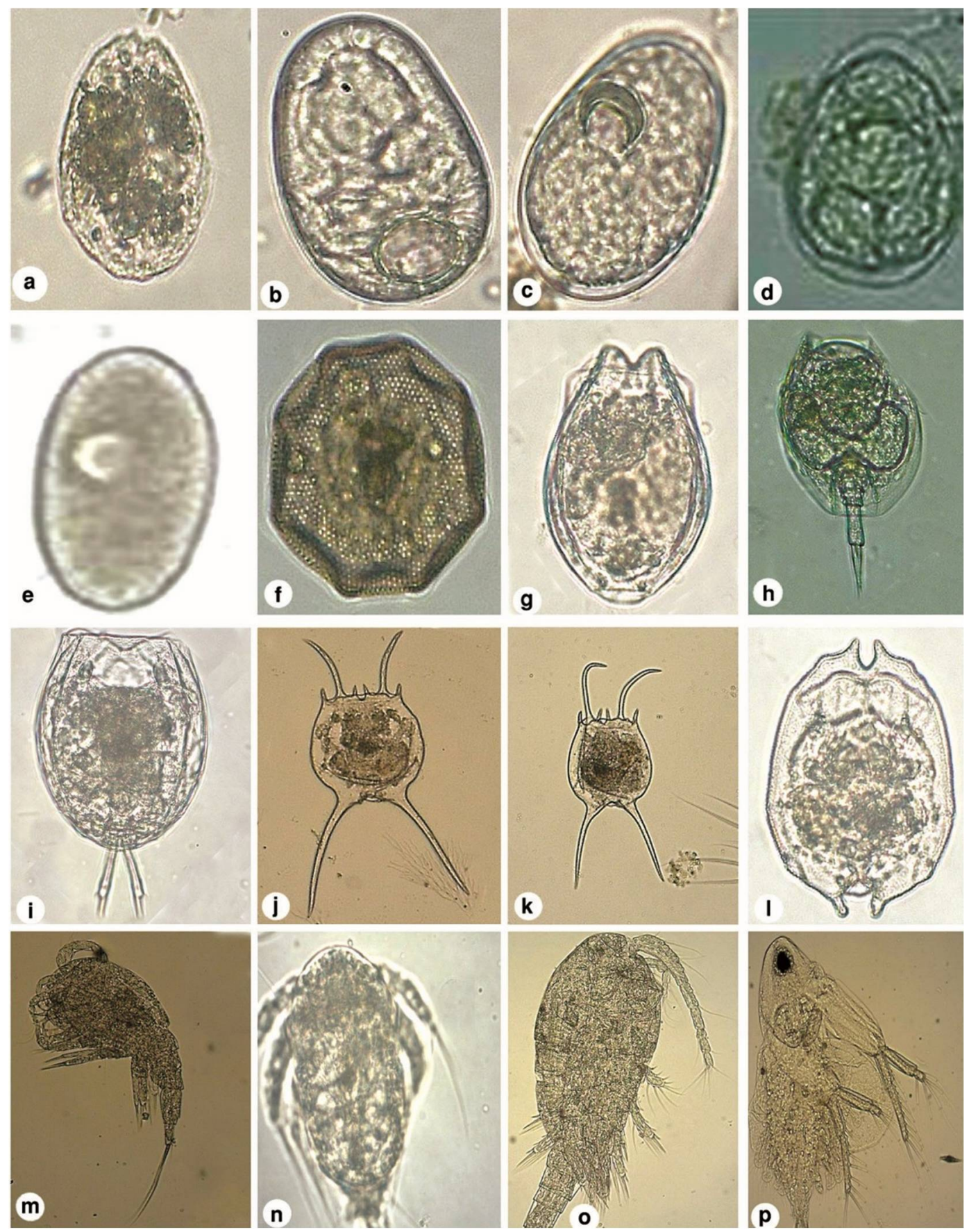

Figs 4a-p: Zoopankton community recorded from the Hakaluki Haor. a. Astasia dangeardii, b-e. Placus luciae, f. Arcella costata, g. Ascomorpha sp., h. Lepadella imbricata, i. Lecanae sp, j-k. Brachionus sp., 1. Brachionus angularis, m. Cyclops sp. (side view), n. Nauplii sp., o. Cyclops sp. (side view), p. Diaphanosoma sp. 
From the floristic standpoint of the two Haor ecosystems, very little similarity has been observed. As a whole, eight phytoplankton taxa viz. Eudorina sp., Pleuodorina sp., Pandorina morum, Dictyosphaerium pulchellum, Coelastrum microporum, Closterium kuetzingianum var. kuetzingianum, Pediastrum duplex and Fragilaria virescens were found common in occurrence in both the Haor Ecosystems ${ }^{(4-5)}$.

Regarding the fish kill events in the Haors in April 2017, the low oxygen and high ammonium might be responsible. The latter compound was recorded $>1.0 \mathrm{mg} \Lambda$, except the Rauar Station of Tanguar Haor. Bhuiyan et al. (2-5) observed the mean water transparency $2.51 \mathrm{~m}$, SRP $17.19 \mu \mathrm{g} /$ and chl-a 5.47 in Tanguar Haor ${ }^{(2-5)}$, while the measurements carried out in the Hakaluki Haor during the fish kill event were: water transparency $1.24 \mathrm{~m}$, SRP $12.50 \mu \mathrm{g} \Lambda$ and chl-a $38.05 \mu \mathrm{g} \Lambda$. Tanguar Haor has a relatively deeper basin compared to Hakaluki and holding little clearer water, as it is evident by the data on Secchi Disc value and chl-a measured for both the Haors. The catchment characteristics of both the Haor ecosystems might be responsible for the concentration of SRP which is a governing element for the phytoplankton biomass. It is, therefore, suggested that an elaborative study covering all the climatic seasons of Bangladesh for Hakaluki Haor should be carried out.

\section{Acknowledgements}

The authors would like to express their gratitude to the University Grants Commission of Bangladesh for providing financial support to conduct the study (Project ID: Bio-11/2017/151). They are deeply indebted and do express their heartfelt thanks to Dr. Md. Niamul Naser, Professor and Chairman, Department of Zoology, University of Dhaka for his kind help to confirm and identify some taxa of zooplankton.

\section{References}

1. Islam N (ed) 2017. National atlas of Bangladesh. Asiatic Soc. Bangladesh, Dhaka. 442 pp.

2. Bhuiyan MAH, SAMS Islam, A Kowser, MR Islam, SA Kakoly, K Asaduzzaman and MKhondker 2019a. Phytoplankton in relation to water quality of Tanguar haor ecosystem, Bangladesh: 1. Rauar Station. Dhaka Univ. J. Biol. Sci. 28(2): 131-138.

3. Bhuiyan MAH, SAMS Islam, A Kowser, MR Islam, SA Kakoly, K Asaduzzaman and M Khondker 2019b. Phytoplankton flora of Tanguar haor ecosystem in Bangladesh: cyanophyta, Pyrrhophyta, Chrysophyta and Euglenophyta. J. biodiver. conserv.

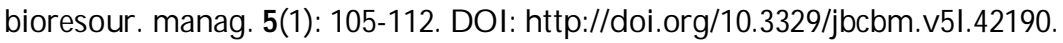

4. Bhuiyan MAH, A Kowser, SAMS Islam, MR Islam, M Mohid, SA Kakoly, K Asaduzzaman, and M Khondker 2020a. Phytoplankton in relation to water quality of Tanguar Haor Ecosystem, Bangladesh: 2. Watch Tower Station. Dhaka Univ. J. Biol. Sci. 29(1): 9-18.

5. Bhuiyan MAH, A Kowser, SAMS Islam, M Mohid, MR Islam, SA Kakoly, K Asaduzzaman, and M Khondker 2020b. Phytoplankton flora of Tanguar Haor Ecosystem of Bangladesh: Chlorophyta. J. biodivers.conserv. bioresour. manag. 5(2): 101-106. DOI: https://doi.org/ 10.3329 亿bcbm.v5i2.44920. 
6. Islam AKMN and N Paul 1978. Hydrobiological study of the haor Hakaluki in Sylhet. J. Asiatic Soc. Bangladesh (Sci.) 4(1): 83-91.

7. Islam MT, MM Rahman and H Mahmud 2014. Physicochemical attributes of water of Hakaluki Haor, Sylhet, Bangladesh. Jahangirnagar Univ. J. Biol. Sci. 3(2): 67-72.

8. Welsch PS 1948. Limnological Methods. McGraw-Hill Book Co. Inc., New York. pp. 381.

9. Marker AFH, EA Nusch, H Rai and B Riemann 1980. The measurement of photosynthetic pigments in freshwaters and standardization of methods: conclusions and recommendations. Arch. Hydrobio. Beih. Ergebn. Limnol. 14: 91-106.

10. Murphy J and Riley RP 1962. A modified simple solution method for the determination of phosphate in natural water. Anal. Chim. Acta. 27: 31-36.

11. Wetzel RG and GE Likens 2000. Limnological Analysis. W.B. Saunders Co. Philadelphia. pp. 357.

12. Müller R and Wiedemann F 1955. Die Bestimmung des Nitrates in Wasser. Jahrbuch fur Wasserchemcie und Wasserreinigungtech. 12: 247-271.

13. Ahmed ZU, ZNT Begum, MA Hassan, M Khondker, SMH Kabir, M Ahmad, ATA Ahmed, AKA Rahman and EUHaque (eds.) 2008. Encyclopedia of Flora and Fauna of Bangladesh. Vol. 3.Algae.Chlorophyta (Aphanochaetaceae-Zynemataceae. Asiatic Society of Bangladesh, Dhaka. pp. 812.

14. Ahmed SU, M Khondker, ZNT Begum, MA Hassan, SMH Kabir, M Ahmad, ATA Ahmed and AKA Rahman 2009 (eds). Encyclopedia of Flora and Fauna of Bangladesh. Vol. Algae. Charophyta-Rhodophyta (Achnanthaceae to Vaucheriaceae), Asiatic Society of Bangladesh. Dhaka. pp. 543.

15. Khondker M, A Aziz, MA Alfasane and RA Bhuiyan 2009. New records of freshwater dinoflagellates from Bangladesh. Bangladesh J. Bot. 38(1): 65-69.

16. Hustedt F 1930. Die Suesswasserflora Mitteleuropas. Heft. 10, Bacillariophyta (Diatomeae). Verlag Gustav Fisher, Jena. pp. 466.

17. Ling HU and PA Tyler2000. Australian Freshwater Algae (exclusive of diatoms). Bibl. Phycol. Bd. 105.J. Cramer, Berlin. pp. 643.

18. Prescott GW 1982. Algae of the Western Great Lakes Area. Otto Koeltz Sci. Publ., W-Germany. pp. 977.

19. Edmondson WT (ed.) 1918. Freshwater Biology (2nd Edn.). John Willey \& Sons, Inc. New York. pp. 1248.

(Manuscript received on 13 March, 2020; revised on 25 October, 2020) 